\title{
Erratum to: Gossypiboma presenting as mesosigmoid abscess
}

\author{
D. Paramythiotis - A. Michalopoulos $\cdot$ V. N. Papadopoulos $\cdot$ D. Panagiotou \\ L. Papaefthymiou $\cdot$ E. Digkas $\cdot$ S. Salonikidis $\cdot$ G. Basdanis
}

Published online: 28 September 2011

(C) Springer-Verlag 2011

\section{Erratum to: Tech Coloproctol \\ DOI 10.1007/s10151-011-0735-z}

In the original published article, ": an experimental study" was erroneously added at the end of the article title.

The correct title is given above.

The online version of the original article can be found under doi:10.1007/s10151-011-0735-z.

D. Paramythiotis $(\bowtie) \cdot$ A. Michalopoulos .

V. N. Papadopoulos · D. Panagiotou · L. Papaefthymiou ·

E. Digkas · S. Salonikidis · G. Basdanis

1st Propedeutic Surgical Department, Aristotle's University

of Thessaloniki, A.H.E.P.A. University Hospital,

Tzavella 2D Str, Pylaia, 55535 Thessaloniki, Greece

e-mail: danosprx@med.auth.gr; danosprx1@hotmail.com 